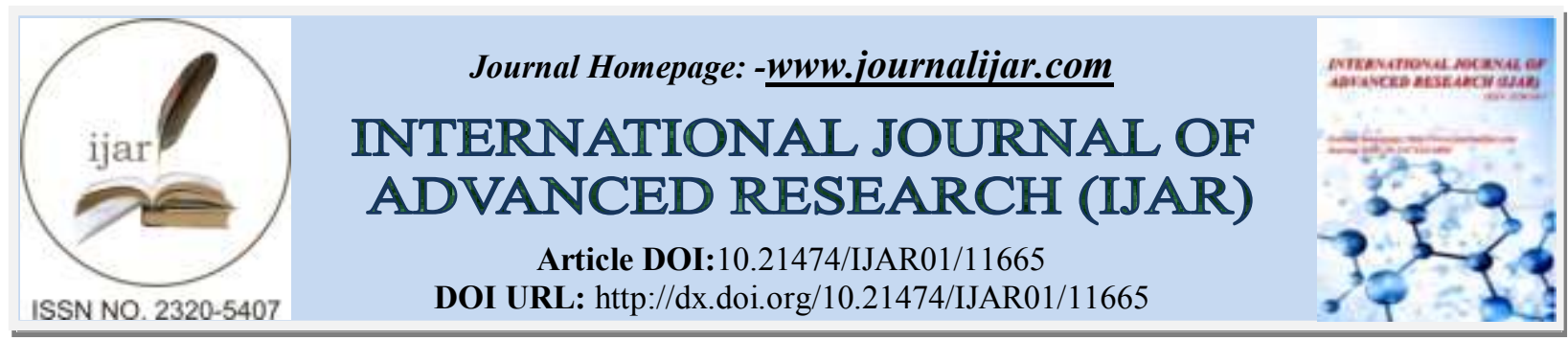

RESEARCH ARTICLE

\title{
AWARENESS AND ADAPTATION TO CLIMATE CHANGE IN ARID AND SEMI-ARID LANDS. A CASE OF BARINGO COUNTY, KENYA
}

Dr. Ednah Chemutai Koskei

Kabarak University, P.O. Box Private Bag, Kabarak, 20157, Kenya.

\section{Manuscript Info}

Manuscript History

Received: 10 July 2020

Final Accepted: 14 August 2020

Published: September 2020

Key words:-

Awareness, Adaptation, Climate

Change, Arid And Semi-Arid Lands

\begin{abstract}
The main objective of this study was to determine the awareness and adaptation to climate change in Baringo County. The study adopted a descriptive survey design. Purposive sampling technique was used to obtain the sample. A total of 376 households were selected for the study. Questionnaire, key informant interview schedule and observations were the main instruments of data collection. Analysis of data was done using the SPSS. Percentages were used to analyze awareness and adaptation to climate change. About $70 \%$ of the households in the area are aware of climate change and have adapted to itby using small containers, storage tanks and dams.However, many households use basic methods and technologies yet these are arid and semi-arid lands (ASALS) where droughts are frequent and rains more erratic. There is need to increase awareness on improved technologies in Baringo in order to adapt to changing climate.
\end{abstract}

Copy Right, IJAR, 2020,. All rights reserved.

\section{Introduction:-}

Climate changes worldwide. Developing countries, Arid and Semi-Arid Lands (ASALs) and the poor in society are the most vulnerable and likely to be hit hardest by climate change due to their low adaptive capacity (IPCC, 2007b). According to Okoth-Ogendo, Ogallo, Hulme, Conway ..... \& Downing (1995), climate change and climate variability are already taking place in Kenya and their effects are being felt. The climatic factors of greatest economic and social significance are temperature and rainfall with the latter, eliciting more concern than the former. Rainfall in Kenya is variable, especially in ASALs (NCEA, 2015). Climatic variations in Kenya have been associated with global climatic systems such as the El-Niño/South Oscillation (ENSO) phenomenon and QuasiBiennial Oscillation (QBO) (Ogallo, 1992; NCEA, 2015). They have also been associated with shifts in dry land or desert margins and the rise or fall of water levels in lakes and rivers. For instance, lakes Turkana, Baringo, Bogoria, Elementaita, Nakuru, Naivasha and Magadi are estimated to have occupied much larger area in the Holocene period (Okoth-Ogendoet al., 1995). As in the rest of the tropical regions, droughts and floods are common phenomena in Kenya. The two are triggered by the same factors and can be either mild or disastrous. They are more common in the arid and semi-arid regions.

Baringo County, like the rest of the ASAL areas in Kenya, is characterized by low and erratic rainfall, low fertility, fragile soils with low nutrient content, low organic matter content and poor physical properties for water infiltration and storage (Muchena\& van der Pouw, 1981). In 1970, there were seven perennial rivers in Lake Baringo catchment (Jenny and Svensson, 2002). Today only two of them remain with significantly reduced water discharges during dry seasons. The rest of the rivers have become seasonal like the other watercourses in the area (Odada, 
Onyando\&Obudho, 2006). Water currently in use in Baringo is few rivers, traditional river wells, boreholes, lake and springs (RoK, 2006).

The extent and scope of regional climate change impacts depend on the degree of mitigation (Adger, Khan \& Brooks, 2003). Adaptation to climate is not a new phenomenon. Throughout human history, societies have adapted to climate variability (Burton, Diringer\& Smith, 2006). Many countries and regions in the world are already taking actions that will help them manage the challenges of climate variability. Africa region is one of them. The approach that each has followed is specific to the context of the region or the country. A number of adaptation measures that can be used to reduce vulnerability to rainfall variability have been suggested by several studies. These include: access and use of seasonal rainfall forecasts, use of water conservation techniques, rainwater harvesting (RWH), multiple and efficient use of water resources, migration to new areas and protecting and restoring stream and river banks to ensure good water quality and safe guarding water quantity by building flood defenses and raising the levels of dykes (NRC, 2010; Burton et al., 2006; Smith, 2012).

The Kenyan government has introduced reforms in the water sectors through the Water Act of 2002 with a view of conserving and improving water access in Kenya. The water sector reforms appear to have done well in establishment of institutional framework with little impact on improving water accessibility. There is also the National Climate Change Response Strategy (2010) and National Climate Change Action Plan (2012) - policy documents that provide guidelines on how to address the challenge of climate variability in Kenya. There are also efforts by development agencies to improve water accessibility, especially in ASAL areas of Kenya. Notable ones are CARE International, World Vision, Kenya Rainwater Association (KRA) and UNDP. The contribution of development agencies appear scattered in across the country. Despite the efforts, households in Baringo County continue to suffer from water inaccessibility; a situation usually exacerbated by climate change and variability. Little has been done at local level to safeguard against the uncertainties induced by climate change and even where there is contribution, there is no assessment on its awareness by households. In order to ensure safe and adequate water for all Kenyans, the country needs innovative technologies and proactive strategies that will empower its citizens in meeting their water demands. This study therefore sought to establish awareness and adaptation strategies to climate change in Baringo County.

\section{Literature Review:-}

Kenya has in recent years had its share of climate-related impacts including; prolonged droughts; frost in some of the productive agricultural areas; hailstorms; extreme flooding; receding lake levels; drying of rivers and other wetlands; among others leading to large economic losses and adversely impacting food security (RoK, 2013). More frequent and severe droughts were perceived to be responsible for the reduced water level in Lake Baringo and intermittency of most rivers which were previously permanent. Lake Baringo was reported to have receded for approximately 2 kilometers. According to Kipkorir (2002), while annual rainfall has been decreasing in Baringo, annual and monthly rainfall has been homogenous between 1965 and 2000 implying that the rainfall amount per rainy day is increasing. The shrinking of Lake Baringo was attributed to frequent droughts and siltation due to soil erosion in the lake Basin. Onyando, Kisoyan\&Chemelil (2005) reported a decrease in the depth of lake from 8 meters in 1969 to 1.7 meters in early 2003. A study conducted by Jenny and Svensson (2002) in Baringo found that a number of streams have dried out and become seasonal in the past few decades. The study also reported fluctuating water discharge amounts in rivers such as Perkerra. The 2010 National Climate Change Response Strategy (NCCRS) recognized the importance of climate change impacts for Kenya's development. This National Climate Change Action Plan developed in 2012 is the logical next step to enable Kenya to reduce vulnerability to climate change and to improve the country's ability to take advantage of the opportunities that climate change offers (RoK, 2013).

Due to the extent of likely repercussions of a changing climate on human and natural systems, it has become a matter that man need to understand and respond to. According to Islam, Sallu, Hubacek\& Paavola (2014), adaptation is inevitable to address the impacts of climate variability and change. The major aim in any climate change contest is to identify options for reducing the extent and effects of future climate change (Anita, Dominic \& Neil, 2010). Adaptation to changes in climate is not anything new. Throughout history, human societies have frequently demonstrated a strong capacity for adapting to different climates and environmental changes (Adger, Agrawala, Mirza, Conde, O'Brien, Pulhin, Pulwarty, Smit \& Takahashi, 2007).However, the current rate of global climate change is unusually high compared to past changes that society has experienced (USGCRP, 2009). In an increasingly interdependent world, negative effects of climate change on one population or economic sector can 
have repercussions around the world (USGCRP, 2009). Kenya was among the first non- Least developed countries in Africa to develop government plans for responses to climate change across key economic sectors (Okoti, Maina\&Newsham, 2013). Kenya's recent National Climate Change Response Strategy (NCCRS), (RoK 2010) and the national climate change implementation framework (2012) illustrate that climate change has acquired the status of a key national policy challenge.

Households especially in the more arid and semi-arid environments where rainfall variability impacts most strongly on water resources, have developed coping strategies to safeguard against the uncertainties induced by seasonal and annual rainfall variability. These strategies include: Access and use of seasonal rainfall forecasts, use of water conservation techniques, rainwater harvesting $(\mathrm{RWH})$, using scarce water resources more efficiently, migration to new areas and protecting and restoring stream and river banks by building flood defenses and raising the levels of dykes (Smith, 2012;UNEP, 2006). The strategies can be applied at either local, regional, national or the international level. Ogalleh, Vogl, Eitzinger\& Hauser (2012), found that climatic variability in Kenya is increasing and the smallholders in the community deal with its negative impacts by use of diversification of crop varieties, migration and sale of livestock. Okotiet al. (2013) found that to deal with immediate climate change impacts in Kenya, Kenyans perceived the need to focus on increasing vegetation cover, expand carbon sinks and bridge the gap between the dry spells.

\section{Methodology:-}

The study used purposeful sampling and stratified proportionate random sampling procedures to obtain the sample. Within Baringo County, the locations were stratified according to the agro-ecological zones. These are LM 5 (lower Midland), LH 2 (Lower Highland) and IL 6 (Inner Lowland). Lembus Central, Salabani and Ribkwo locations was purposefully selected for the study. They were selected because of having Agro-ecological zones LH2, LM5 and IL6, respectively toensure proper representation of the respondents within the whole Baringo County area coverage. Lastly, random selection of the respondents within locations was made proportionate to the population of each location as per the household census report of 2009 (RoK, 2010). The study targeted 376 households which constituted $7.9 \%$ of the total number of households in the three agro ecological zones. The selection of respondents was informed by household population by location level. This information was acquired from the County Development Officer at Kabarnet, the County headquarters. Lembus Central location has a population of 2,668 households, while Salabani has a population of 963 households and Ribkwo 1128 households. These were the three strata where proportional representation was obtained. 211 households in Lembus Central, 76 in Salabani and 89 in Ribkwo location was selected. A total of 376 respondents were selected for the study. Their participation during the interviews was, however, based on random sampling.

As for the key informants, purposive sampling was used to select those to be interviewed. These were selected from among meteorologists, NGO officers, chiefs, NDMA officers and water officers based on their positions of authority. These key informants were selected for the interview in consideration that they have insights on the subject of climate change and adaptation to it in the County.

The data were obtained from households and key informants through personal interviews by use of structured questionnaire and Key Informant Interview Schedule. The study focused mainly on household heads for interviewing to ensure uniformity of data collection process. The questionnaire was used to collect data from households on barriers to adoption of RWHT. The questionnaire was administered to all the 376 households in the study area. Key Informant Interview Schedule was used to collect in-depth data on awareness and adaptation to climate change. Observation was used to supplement and enrich data collected via the interview.

\section{Results:-}

About $70 \%$ of the households in Baringo County were aware of climate change and adaptation strategies that existed within their local context. A small proportion of households (30\%) were not aware of the changing climate and this may be attributable to inadequate dissemination of information and skills with regard to adaptation. The distance to be covered and times spend collecting water in the event of water scarcity further amplified the awareness of climate change and the need for adaptation. The distance covered in search of water is relatively far during water scarcity period. This makes people, especially women and children whose work is to ensure that there is water in the household (RoK, 2006), spend a lot of energies and time as well as travel longer distances in search of water during this period. 
The study sought to find out how awareness was created. Figure 1 illustrates four major channels used to sensitize households on adaptation to climate change. Majority of the governmental and non - governmental officers saidthat they created awareness through group meetings. This can be the very reason whymajority of the households (71\%) revealed that such awareness is created by fellow villagers. In addition, school training and other sources such as radio, television and own initiatives were also mentioned. However, the finding that a section of the respondentswho hadsome knowledge onadaptation strategies implies that climate change phenomenais not new in the sampled locations. The NGOs, and to a limited extent government extension staff, are just trying to revitalize utilization of RWHT and training residents in better ways of constructing rainwater harvesting structures. Barghouti and Le Moigne (1990) found that NGOs with few private sectors played an important role in implementing and adopting water harvesting techniques all over Kenya. These organizations were well appreciated by the community and were considered to be most efficient compared to government driven programs. According to Masuki, Mutabazi, Tumbo, Rwehumbiz\&Hatibu (2005), awareness exposes someone to information and therefore creates knowledge.

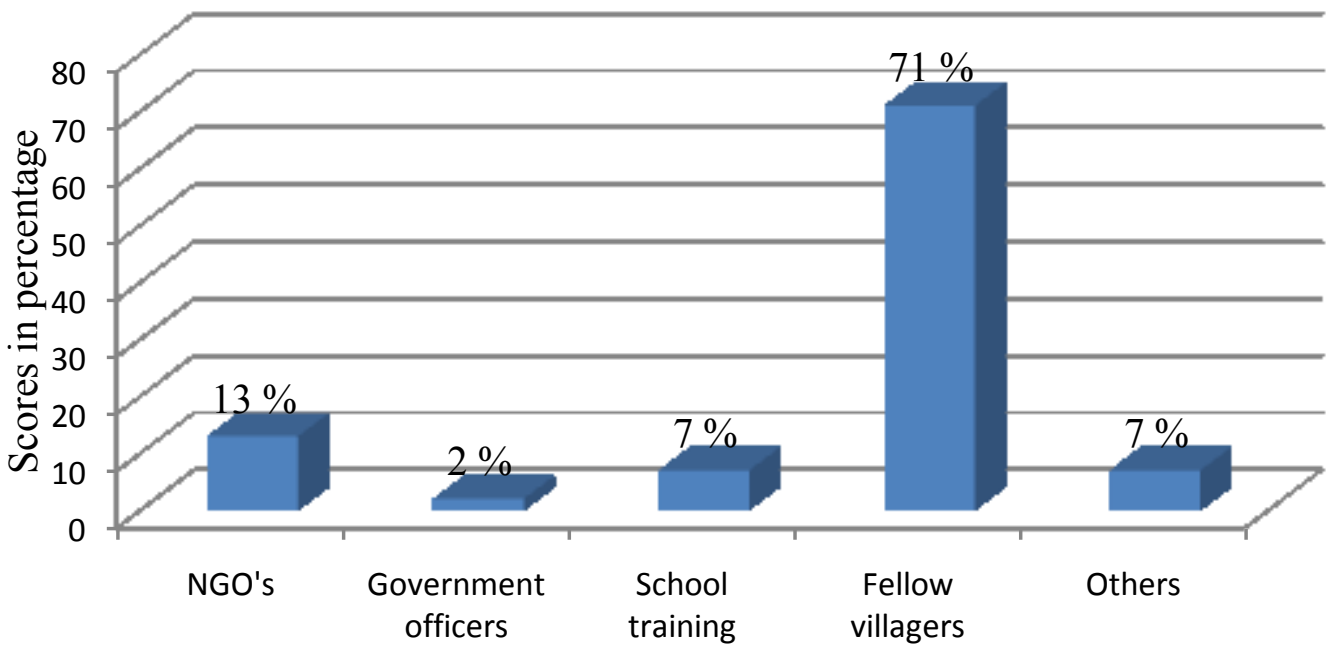

Sources of information for households

Figure 1:- Sources of information and knowledge on climate change.

Majority of the households (60\%) in BaringoLowlands collect rainwater using dams to bridge the dry season. Earth and sand dams are constructed to collect water from river valleys for livestock and domestic purposes. Surface runoff occurs mostly on flat to gently sloping terrains and hardly contributes river flows due to low rainfall intensities in this part hence it is either captured in dams or re-infiltrates before reaching the river. The presence of luvisols in lowlands is suitable for surface runoff water harvesting because the subsurface layer lying at 1 to $3 \mathrm{~m}$ depth is clayey, favorably minimizing seepage losses (Pachpute, Tumbo, Sally \&Mul, 2009). Land evaluation of RWH in a surface reservoir in the four Great Horn of African countries (Ethiopia, Kenya, Tanzania and Uganda) revealed that, it was slowly being adopted with high degree of success (Kiggundu, 2002). There are many dams in arid areas of Baringo constructed by NGO's (e.g. INTEX construction company and ACTED) in liason with the Government of Kenya. However, earth dams and other open water storage facilities including water wells in Baringo County face the problem of evaporation just as in all other open water storage facilities in ASALs. Erratic rainfall and shortages leading to frequent drought spell, high evapo-transpiration rates have resulted to unreliability and unsuitability of earth dams (Kimani et al., 2015). 


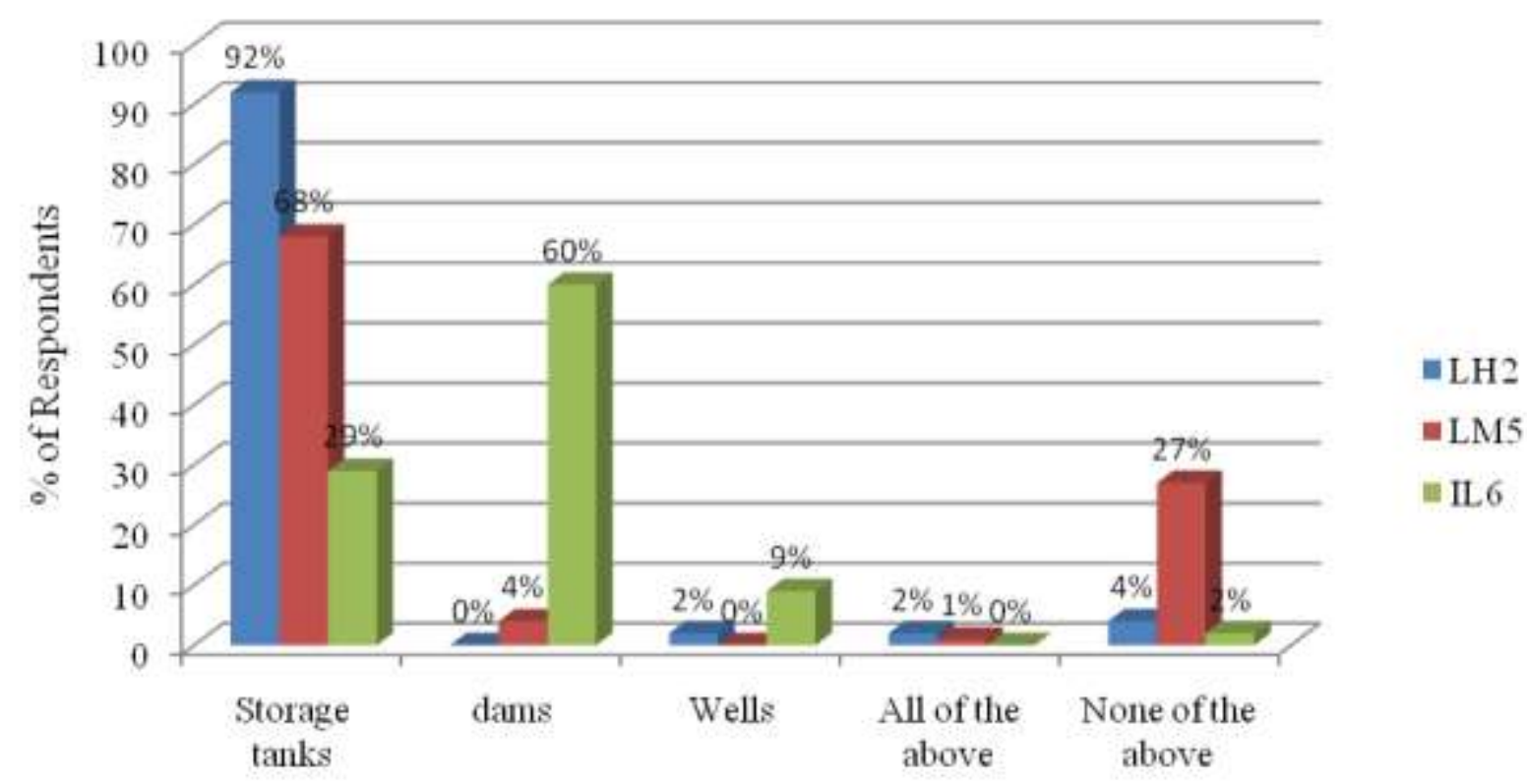

\section{RWHT used by households}

Figure 2:- Adaptation Strategies used by households in Midlands, Lowlands and Highlands.

Most of the households (92\%) in highland and in midlands (68\%) of Baringo practiced rooftop water harvesting techniques (storage tanks) (Figure 2) to adapt to changing climate. Water harvested from rooftops is mainly for domestic uses including drinking and household chores. This technique is so important in the rural highland areas where the terrain is rugged and the villages and hamlets are scattered because it is difficult and expensive for communities to be served by centralized water supply schemes (Binyam and Desale, 2015). The roof water harvesting also has the advantage of being low cost, relatively simple in design (household technology), less laborious and time saving (Alem, 1999). The emergence of this technique these days is due to the increasing shortage of water from the conventional sources, shallow wells, perennial springs, rivers/streams. Binyam and Desale (2015) noted that roof water harvesting practices were confined to urban areas only in the past. However, its use in the rural areas are increasingly becoming important these days as more people in the rural areas are having corrugated roof houses.

\section{Conclusion:-}

Households in Baringo were aware of climate change and adapted to it using a various strategies. They obtained such information from both governmental and non-governmental sources through fellow villagers. There are institutions - government and NGOs working towards enhancing adaptive capacity in Baringo County by creating awareness and training residents in better ways of constructing rainwater harvesting structures. The households practiced both Roof top Rainwater harvesting technologies (such as storage tanks and wells) and Surface runoff RWHT (such as water pans and dams) in their homesteads. Storage tanks were found to be the most widely practiced technique. However, many households used tanks with a capacity of between 200 and 500 liters which cannot hold enough water throughout the year. It has been evident that where water harvesting has been adopted for household water, there has been increased access to water especially during the dry period.

\section{Recommendations:-}

There is need to increase awareness on improved technologies in Baringo in order to adapt to changing climate. Existing rainwater harvesting technologies should be up scaled to guarantee enough and quality water for domestic and livestock use during dry spell. There is also need to strengthen adaptation capabilities of households in the areas that are weak.

\section{References:-}

1. Adger, W.N., Agrawala, S., Mirza, M.M.Q., Conde, C., O’Brien, K., Pulhin, J., Pulwarty, R., Smit, B,.\& Takahashi, K. (2007). In M.L., Parry, O.F. Canziani, J.P. Palutikof, P.J., Van der Linden, and C.E. Hanson 
(Eds.), Assessment of adaptation practices, options, constraints and capacity. Climate Change 2007: Impacts, Adaptation, and Vulnerability. Contribution of Working Group II to the Fourth Assessment Report of the Intergovernmental Panel on Climate Change (pp. 717-743). Cambridge, United Kingdom: Cambridge University Press.

2. Alem, G. (1999). Rainwater Harvesting In Ethiopia: An Overview. Integrated Development for Water Supply and Sanitation. 25thWEDC Conference (pp. 387-390). Addis Ababa: Ethiopia.

3. Anita, W., Dominic, M. \& Neil, A. (2010). Climate Change and Agriculture, Impacts, Adaptation and Mitigation, OECD Publication.

4. Barghouti, S., \&Moigne, G. L. (1990). Irrigation in Sub-Saharan Africa: The development of Public And Private Systems (No. 123).

5. Binyam, A. Y., \&Desale, K.A. (2015). Rainwater Harvesting: An Option for Dry Land Agriculture in Arid and Semi-Arid Ethiopia. International Journal of Water Resources and Environmental Engineering, 7(2), 17-28.

6. Burton, I., Diringer, E., \& Smith, J. (2006). Adaptation to Climate Change: International Policy Options. Arlington, USA: Pew Centre on Global Climate Change. Retrieved from http://www.c2es.org/docUploads/PEW_Adaptation.pdf

7. (IPCC) Intergovernmental Panel on Climate Change. (2007). Climate change 2007: impacts, adaptation and vulnerability. In: Parry M. L., Canziani, O.F., Palutikof, J.P., Vander Linden, P.J., Hanson, C.E. (Eds). Contribution of working group II to the fourth assessment report of the Intergovernmental Panel on Climate Change.Cambridge: Cambridge University Press

8. Islam, M., Sallu, S., Hubacek, K., \& Paavola J. (2014). Limits and Barriers to Adaptation to Climate Variability and Change in Bangladeshi Coastal Fishing Communities, Marine PolicyElsevier Journal, 43 (208-2016).

9. Jenny, J., \&Svensson, J., (2002).Land Degradation in the Semi-Arid Catchment of Lake Baringo, Kenya. A Minor Field Study of Physical Causes With a Socioeconomic Aspect

10. Kiggundu, N. (2002). Evaluation of Rainwater Harvesting Systems in Rakai andMbarara Districts, Uganda. GHARP (Greater Horn of Africa Rainwater Partnership). Case Study Report. GHARP, Kenya Rainwater Association: Nairobi, Kenya.

11. Kimani, W. M., Gitau, A. N. \&Ndunge, D. (2015). Rainwater Harvesting Technologies in Makueni County, Kenya.International Journal of Engineering and Science.5 (2), 39-49.

12. Kipkorir E.C (2002). Analysis of Rainfall Climate on the Njemps Flats, Baringo District, Kenya. Journal of Arid Environment, 50, 445-458.

13. Masuki, K. F., Mutabazi, K. D., Tumbo, S. D., Rwehumbiza, F. B., \&Hatibu, N. (2005). Determinants of farmlevel adoption of water systems innovations in dryland areas: the case of Makanya Watershed in Pangani River Basin, Tanzania. Retrieved from http://agris.fao.org/agris-search/search.do?recordID=QL2012001930

14. Muchena, F. N. \& Van der Pouw, B. J. A. (1981). The Soil Resource of the Arid and Semi Arid Areas of Kenya. Paper presented in International Workshop on Strategies for Developing the Resources of the Arid and Semiarid Areas of Kenya (4-8August 1981). Kenya: Nairobi.

15. NCEA (Netherlands Commission for Environmental Assessment). (2015).Climate change Profile Kenya. Retrievedfromhttp://api.commissiemer.nl/docs/os/i71/i7152/climate change profile kenya.pdf

16. NRC (National Research Council). (2010). Adapting to the Impacts of Climate Change. National Research Council. Washington, DC, USA: The National Academies Press.

17. Odada, E.O., Onyando, J.O., \&Obudho, A. P. (2006). Lake Baringo: Addressing Threatened Biodiversity and Livelihoods. Lakes and Reservoirs. Journal of Research and Management,11(4),287-299.Retrievedfrom http://www.worldlakes.org/uploads/03 Lake Baringo_27February2006.pdf

18. Ogalleh, S.A., Vogl, C.R., Eitzinger, J., \& Hauser, M. (2012). Local Perceptions and Responses to Climate Change and Variability: The Case of Laikipia District, Kenya. Journal of Sustainability, 4(12):3302.

19. Ogallo, L.A. (1992). Global Climate Change: Impacts on Kenya. Global Environmental Concerns (pp. 7-21). Kenya: Kenya Museum Society.

20. Okoth-Ogendo, H.W.O., Ogallo, L.J., Hulme, M., Conway, D., Kelly, P.M. Subak, S., \& Downing, T.E. (1995). Global Climate Change and the Environment. In: A Climate for Development: Climate Change Policy Options for Africa (pp. 11-46). Nairobi, Kenya: African Centre for Technology Studies (ACTS) Press.

21. Okoti, M., Maina, I., \&Newsham, A. (2013). Agriculture and Climate Change in Kenya: Climate Chaos, Policy Dilemmas. Future Agricultures. Working Paper No. 070. Retrieved from www.future-agricultures.org

22. Onyando, J.O., Kisoyan, P., \&Chemelil M.C. (2005).Estimation of Potential Soil Erosion for River Perkerra Catchment in Kenya. Journal of Water Resources management, 19, 133-143

23. Pachpute, J. S., Tumbo, S. D., Sally, H., \&Mul, M. L. (2009). Sustainability of Rainwater Harvesting Systems in a Rural Catchment of Sub-Saharan Africa. Journal of Water Resources Management, 23, 2815-2839. 
24. RoK (Republic of Kenya). (2006). Kenya Drought Monitoring Bulletin - Baringo District.Retrievedfromhttp://reliefweb.int/report/kenya/kenya-drought-monitoring-bulletin-baringo-district

25. RoK (Republic of Kenya). (2013). Baringo County Budget Implementation Report. Nairobi, Kenya: Government Printers.

26. RoK (Republic of Kenya). (2010). Kenya National Bureau of Statistics: 2009 Kenya Population and Housing Census, Volume 1A. Nairobi, Kenya: Government Printers.

27. Smith, C. (2012). How Rainfall Variability, Food Security and Migration Interact. United Nations University. Retrieved from http://unu.edu/publications/articles/how-rainfall-variability-food-security-and-migrationinteract.html

28. UNEP (United Nation Environmental Program). (2006). Harvesting Rainfall a Key Climate Adaptation Opportunity for Africa. Retrieved from http://www.unep.org/Documents

29. USGCRP (United States Global Change Research Program). (2009). Global Climate Change Impacts in the United States .In Karl, T.R., J.M. Melillo, and T.C. Peterson (Eds.). United States Global Change Research Program. New York, NY, USA: Cambridge University Press. 